Síntese - Rev. de Filosofia

v. 38 N. 122 (2011): 381-398

\title{
RELIGIOUS EXPERIENCE ACCORDING TO BERNARD
}

\section{LONERGAN}

\author{
(A experiência religiosa segundo Bernard Lonergan)
}

Louis Roy *

Abstract: This article purports to introduce readers to Bernard Lonergan's understanding of religious experience. It contrasts the emphasis placed on doctrine by ancient Christian doctors during premodern times, with a typically modern way of putting a stress on religious experience. It describes Lonergan's view of human intentionality. It explains what he calls 'realms of meaning.' It explicates the interrelations between the several components of religious experience. Lastly it characterizes Lonergan's project as an integration of faith and reason.

Keywords: Lonergan, Schleiermacher, religious experience, intentionality, meaning, faith and reason.

Resumo: Este artigo pretende introduzir os leitores na compreensão da experiência religiosa proposta por Bernard Lonergan. $O$ texto contrapõe a ênfase posta na doutrina pelos antigos doutores cristãos ao longo da época pré-moderna com a maneira tipicamente moderna de acentuar a experiência religiosa, abordando os seguintes tópicos: (1) a concepção de Lonergan da intencionalidade humana; (2)

\footnotetext{
* Louis Roy, O.P., holds a Ph.D. from the University of Cambridge. After teaching philosophy and theology for twenty years at the Jesuit University of Boston College, he is now Professor of theology at the Dominican University College in Ottawa. He is the editor of the French translation of Lonergan's Method in Theology, entitled Pour une méthode en théologie (Montreal: Fides, and Paris: Cerf, 1978).
} 
a noção do que ele chama de "reinos de significado"; (3) as interrelações entre os diversos componentes da experiência religiosa; (4) finalmente, a caracterização do projeto de Lonergan de uma integração de fé e razão.

Palavras-chave: Lonergan, Schleiermacher, experiência religiosa, intencionalidade, significado, fé e razão.

$\mathrm{T}$ The Canadian Jesuit Bernard Lonergan (1904-84) is well-known in the English-speaking world, principally for his two most important books: Insight: A Study of Human Understanding, which first appeared in 1957, and Method in Theology, which first appeared in 1972. ${ }^{1}$ University of Toronto Press is currently publishing the series Collected Works of Bernard Lonergan, which will comprise twenty-five volumes; so far two-thirds of those volumes have seen the light of day.

This essay is divided into six sections. First, it will briefly contrast Lonergan's interest in religious experience with the emphasis placed on doctrine by ancient Christian doctors during premodern times, which cover the long period lasting from the first to the fifteenth century. Second, it will initiate a comparison between Lonergan's thought and a typically modern way of putting a stress on religious experience. Third, it will describe his view of the human person as a dynamic intentionality. Fourth, it will depict what he calls 'realms of meaning.' Fifth, it will explicate the interrelations between the several components that he carefully sets within religious experience. Lastly it will suggest an interpretation of his project as an integration of faith and reason.

\section{Religious Experience in Premodern Times}

The concept of religious experience is a modern one. Admittedly it was prepared by the biblical revelation, with the accent that this revelation increasingly placed upon the individual conscience, as is clear in Ezekiel, chapter 18, and throughout the New Testament, particularly in the free decision to believe in Jesus and be baptized. During the first fifteen centuries of Christianity, the early proclamation of the Gospel was heard and the standard patristic-medieval presentation of the Christian belief was

\footnotetext{
${ }_{1}$ Insight: A Study of Human Understanding, ed. Frederick E. Crowe and Robert M. Doran, Collected Works of Bernard Lonergan, vol. 3 (Toronto: University of Toronto Press, 1992), and Method in Theology (Toronto: University of Toronto Press, 2003). I shall refer to the latter, in the body of my text, simply by page numbers.
} 
progressively offered. Surely the biblical texts as well as the patristic and medieval writings include religious experience. And yet they are not composed from the perspective of religious experience. Instead, they locate it in the broad context of an history of salvation, because their goal is kerygmatic: to announce what God has done for his people, to proclaim the good news of the great gift that the Father has granted us in Jesus and in the Holy Spirit.

In addition to the kerygmatic concern of the patristic and medieval writers, their other principal interest can be said to be, not experiential, but dogmatic. Their doctrinal teaching is central. They tell the great story of humankind's redemption and they elicit its implications in terms of beliefs and principles of conduct. During that extended period, that is, between the New Testament's time and the Renaissance, only the Desert Fathers, with their short maxims, excerpted their reflections from the standard dogmatic ensemble.

Nonetheless, the general non-experiential preoccupation of the premodern Christians never sapped their ability to convey a deep religious experience. One finds that rich experiential substratum in Paul's letters, in the Gospel according to John, in the profound doctors Gregory of Nyssa, Augustine, pope Gregory the Great, Bernard, Bonaventure, to mention but a few. As evidence, Dom Pierre Miquel refers to the widespread vocabulary of experientia in the Middle Ages. ${ }^{2}$ And even in such objective thinkers as Dionysius the pseudo-areopagite and Thomas Aquinas we notice the expression "experiencing the divine realities" (pathôn ta theia in Greek, pati divina in Latin). ${ }^{3}$

\section{Religious Experience in Modern Times}

At any rate the significance of human individuality emerges decidedly in the sixteenth-century, especially with Martin Luther's reliance on his own experience of grace: a total reversal in his religious attitude, which ushers in a vibrant act of faith and trust in Jesus. This valorization of the person's lively and spirited faith recurs among the German Pietists of the seventeenth century and among the Methodists of the eighteenth century. At about the same time, among spiritual writers of the Grand Siècle, the French noun la mystique is coined to designate the private sphere of mysticism, which is

\footnotetext{
${ }^{2}$ MIQUEL, Miquel, Le vocabulaire latin de l'expérience spirituelle dans la tradition monastique et canoniale de 1050 à 1250 (Paris: Beauchesne, 1989); see also Le vocabulaire de l'expérience spirituelle dans la tradition patristique grecque du IVe au XVIe siècle (Paris: Beauchesne, 1989).

${ }^{3}$ See DIONYSIUS, The Divine Names, 2.9, 648B, and 3.2-3, 681A-684D; Thomas AQUINAS, Summa Theologiae, I, q. 1, a. 6, ad 3; II-II, q. 45, a. 1, ad 2 and a. 2.
} 
often divorced from the rest of church life. ${ }^{4}$ All such examples are ambiguous: we ought neither to denigrate them nor to eulogize them inconsiderately.

However, it is only in the nineteenth century that the concept of religious experience becomes central in theology, namely with Friedrich Schleiermacher. Given his enormous influence, it will be worth our while to dwell for some time on his thinking, so that the difference between him and Lonergan may become evident.

His longest work, Der christliche Glaube ("The Christian Faith") is written from the epistemological perspective of an experiential component, namely the "inward experience" (innere Erfahrung). ${ }^{5}$ In this magnum opus, religion is divided up into an outward and an inward side: "the organization of the communicative expressions of piety in a community is usually called Outward Religion, while the total content of the religious emotions, as they actually occur in individuals, is called Inward Religion" (\$6, Postscript).

In contrast to Lonergan, who makes love the core of religious experience, Schleiermacher infrequently mentions the element of love. One of those very rare occurrences is "the love which wills to perceive" ( $\$ 13$, Postscript). For him, religious experience is self-consciousness, God-consciousness, the feeling of absolute dependence. Its kernel is not love, but the "facility of religious emotions" which, thanks to the redemptive influence of Christ, "becomes a permanent state" (§5.4). The believer thus passes from a state of "being bound" (Gebundensein) to "release" (Erlösung, §11.2, usually translated by "redemption"; see the English translators' helpful remark, p. 54 , footnote 1). In religious experience, a permanent state of harmony seems to be more characteristic than love.

Another difference between Schleiermacher and Lonergan is the fact that religious experience is extolled at the expense of dogma. Religion (Religion in German) or piety (Frömmigkeit) amounts to the consciousness (Bewußtsein) that is shared in the Church; belief (Glaube), far from possessing a permanent value, simply conveys this consciousness at a particular epoch. The title of Schleiermacher's masterpiece denotes this contextualism: Der christliche Glaube nach den Grundsätzen der evangelischen Kirche im Zusammenhange dargestellt. Unfortunately the English edition leaves out most of it. The full title can be rendered as: The Christian Faith systematically presented according to the principles of the Evangelical Church.

\footnotetext{
${ }^{4}$ See CERTEAU, Michel de, "Mystique," in Encyclopedia Universalis (Paris, 1971), vol. 11, 521-526.

${ }^{5}$ SCHLEIERMACHER, Friedrich, The Christian Faith, trans. H. R. Mackintosh and J. S. Stewart (Edinburgh: T. \& T. Clark, 1986), §14.1; the other references to this work will be given in my text.
} 
In his Brief Outline on the Study of Theology Schleiermacher holds the view that dogmatic theology merely represents "the historical knowledge of the present condition of Christianity," that is, "the knowledge of doctrine now current in the evangelical church." 6 This means that "the knowledge of doctrine" of the German Evangelical Church of his time is to be preferred to the knowledge that the Protestants had in previous centuries or to the knowledge that other churches currently profess. Like Kant, Schleiermacher attempts to discover the universal in the subjective. According to The Christian Faith, "piety," which consists in the "feeling of absolute dependence," is "a universal element of life" (§33). ${ }^{7}$ For all his efforts to balance the subjective with the objective, or "piety" with "belief," he clearly leans on the side of a subjective faith and he does not consider church belief as permanently valid. ${ }^{8}$

He himself tells his readers that he selects the doctrines constitutive of his theology according to the following criterion: they must play a role in sustaining the harmonious feeling of dependency, as "accounts of the Christian pious states of mind (frommen Gemütszustände)" (\$15; I have modified the T\&T Clark's translation). ${ }^{9}$ According to this criterion, which is a way of using the concept of religious experience in theology, he disregards or reinterprets in a reductive fashion the following Christian ideas: creation, grace as a supernatural help, the divinity of Christ, the fall, the redemption, the resurrection, the ascension, and the Trinity.

I have just illustrated how Schleiermacher, the father of liberal Protestantism, construes the notion of religious experience. These observations will allow us to pinpoint how dissimilar Lonergan's interpretation is from Schleiermacher's, despite the points they have in common. To conclude this section, I want to add that, in the wake of Schleiermacher, a subjectivistic construal of religious experience has been predominant in the thought of prominent Christian thinkers at the beginning of the twentieth century: the Catholic modernists in France and in England, and Protestant authors such as William James in the United States as well as Ernst Troeltsch and Rudolf Otto in Germany. Interestingly, both Karl Rahner and Lonergan have been

\footnotetext{
${ }^{6}$ SCHLEIERMACHER, Brief Outline on the Study of Theology, trans. Terrence N. Tice (Atlanta: John Knox Press, 1977), §195; see §97.

7 On consciousness, feeling, absolute dependence, and other major concepts in Schleiermacher, see Louis ROY, Mystical Consciousness: Western Perspectives and Dialogue with Japanese Thinkers (Albany, NY: SUNY Press, 2003), chap. 6.

${ }^{8}$ For an analysis of the rather shaky intellectual underpinnings of Schleiermacher's position, see Louis ROY, “Schleiermacher's Epistemology," Method: Journal of Lonergan Studies 16 (1998): 25-46.

${ }^{9}$ In SCHLEIERMACHER's Brief Outline, "the cultivation of doctrine" is tantamount to "the process by which the religious self-consciousness gains clarity" ( $\$ 166)$.

${ }^{10}$ See ROY, Louis, "Rahner's Epistemology and its Implications for Theology," in Lonergan Workshop, ed. Fred Lawrence, vol. 22, 421-439 (Chestnut Hill, MA: Boston College, 2011).
} 
reproached for a subjectivistic stance presumably akin to Schleiermacher's. Unfortunately Rahner is not faultless in this respect, as I have tried to show elsewhere. ${ }^{10}$ Yet, I don't think Lonergan deserves this stricture and we shall see why in the course of this essay. ${ }^{11}$

\section{The Schema of Human Intentionality}

Method in Theology deals, not with the contents of Roman Catholic theology, but, as the title indicates, with a method, which purports to be transcendental, that is, universal. The author's vision of that method is typical of an ecumenical theology, which is extendable to several forms of non-Christian experiences of God, and which, in my opinion, can equally count as philosophy of religion.

Lonergan offers a conception of the human person, which he calls 'intentionality.' The word Intentionalität, which comes from the German philosopher Edmund Husserl, refers to a "tension towards" reality - a tension that constitutes the life of the human being. Drawing on Thomas Aquinas's epistemology, Lonergan lays out how intentionality, as a dynamism, unfolds on four levels. A principal activity characterizes each level: experience, understanding, judgment and decision. Each of these levels requires many other operations, on which we do not have the space to cast an eye in this essay (see Method in Theology, 2-20).

The human subject moves through these four levels in two directions: in an upward movement and in a downward movement. ${ }^{12}$ In the first case, from lower to higher, one starts by taking in data from the senses (sight, hearing, etc.), which in today's world are enhanced electronically. While we share this first level with animals, the other levels are specifically human since they are rooted in acts of questioning. One is able to move from one level to the next through questions. Thus, one moves from level one to level two by asking questions related to the data such as: What is that? What does that mean? How does that work? Why does that happen this way? The answers to these questions are insights, which are acts of understanding, and are expressed in interrelated concepts that form hypotheses.

11 On Rahner's and Lonergan's approaches to religious experience, see ROY Louis,
Transcendent Experiences: Phenomenology and Critique (Toronto: University of Toronto
Press, 2001), 128-141 and 177-178. There is a Spanish translation: Experiencias de
trascendencia: Fenomenología y Crítica, traducido por Carme Castells Auleda (Barcelona:
Herder Editorial, 2006). A French translation will appear next year: L'expérience de
transcendance: Phénoménologie et analyse critique, trans. Pierrot Lambert, Montréal and
Paris: Médiaspaul.
12 See "Healing and Creating in History," in A Third Collection: Papers by Bernard J. F.
Lonergan, S.J., ed. Frederick E. Crowe (New York: Paulist Press, 1985), 100-9, at 106. 
The hypotheses of this second level spontaneously lead us to ask questions of another kind, which allow a critical detachment with respect to our hypotheses. One then progresses to the third level when one asks: Is that really the case? Is that true? Which hypothesis best reflects reality? The answers given are for the most part only probable: they are judgments about reality, which is known in a manner that is imperfect, open to revision, and nevertheless probably correct.

Finally, questions of still a different kind again lead us to progress to the fourth level: What needs to be done in a particular situation? Is there a good that emerges as a thing to be accomplished? Which action is worthy of being undertaken? And, once a relevant value has been identified, must I be consistent and commit myself to it as well as to the people for whom this value makes a difference?

The movement I have just described is from lower to higher. Still, human intentionality also acts from higher to lower: this second movement starts at the fourth level, the level of values, of love, of commitment to others. Here one lives within a horizon, that is a set of interests, a particular sensitivity to aspects of one's life. This fundamental state enables us to more easily accept, at the third level, truths that agree with that which we value, at the fourth level. Next, as we progressively accept these truths, we gain a deeper understanding of their importance, at the second level. Finally, at the first level, we express that which we hold dear (fourth level), consider true (third level) and find meaningful (second level). We then become both creators and communicators of data, which we hope are intelligible, true and value-laden, through the use of the many forms of language at our disposal: scientific, technical, artistic, commonplace language, etc.

\section{Realms of Meaning}

Having dedicated a few paragraphs to Lonergan's account of human intentionality, let us now turn to his unique position about realms of meaning. In section 9 of chapter 3 of Method in Theology, he differentiates a few realms of meaning, which are basic kinds of human activity: common sense, theory, interiority, and religion. In each of those realms, human beings handle meaning in a specific manner. Later in the book he adds two other domains of meaning - scholarship and art - and he explains: "Any realm becomes differentiated from the others when it develops its own language, its own distinct mode of apprehension, and its own cultural, social, or professional group speaking in that fashion and apprehending in that manner" (272). Let us characterize each of the four basic types.

Fundamentally practical, common sense deals with things as concrete, in relation to us, that is, from the point of view of agents interested in achieving 
particular goals. In contradistinction to common sense, theory observes and inspects things in order to find in them generalities, abstract definitions; it aims at comprehending aspects of reality in the interrelations they have among themselves, in their connections, independently of the distinctive perspective of the observer. Interiority concerns the whole of the human subject, as practical, theoretical, religious, scholarly or artistic, that is, as it consciously experiences its psychical, cognitive and affective intentionality. Besides this first kind of interiority, Lonergan identifies a second kind of interiority, religion, which underlies the first kind and about which I shall have much to say presently.

Forms of common sense are innumerable, because every community village, city, region, country - possesses a particular brand of common sense. Beyond common sense, people may become adept at theory. The latter all began in the West with Socrates, who asked for definitions neither too narrow nor too broad - for instance of virtue. Socrates' demanding, intellectual requests baffled his fellow Athenians, whose horizon was bounded by common sense. Plato and Aristotle considerably developed the field of theory, which at that time comprised both philosophy and science. It is only with Descartes that philosophy and science were distinguished. Moreover, because, in the seventeenth century, physics was systematically figuring out its method, it became desirable to differentiate the domains of meaning, especially science from common sense, as well as science from religion. Lack of differentiation accounted for the crisis that ended up with the condemnation of Galileo. For common-sense people and for religious authorities, the sun moved around the earth, whereas the distinguished Italian scientist argued the opposite, basing himself not on common sense or on the Bible, but on empirical and theoretical reasons, which were appropriate in the sphere of physics.

Given the heritage of Plato and, to a lesser extent, of Aristotle in patristic times, Julian Martyr, followed by Clement of Alexandria and most other church fathers, soon realized that they had to teach, no longer exclusively in terms of scriptural categories, most of which belong in the realm of common sense, but with the assistance of philosophical categories. Had they been unwilling to discuss doctrinal matters theoretically, they would have been unable to meet the challenge of Greek and Roman non-Christian thinking; they would have been reputed intellectually inferior, incapable of using reason as competently as their adversaries or competitors - principally the Gnostics, the Platonists and the Stoics.

Lonergan perceived a similar contest for the Church after the Second Vatican Council. That council had distanced itself from the traditional scholastic categories, derived from the world of theory, and it had preferred to talk with biblical words, which belong in the world of common sense. Although he greatly admired the intellectual feat of Thomas Aquinas and incorporated 
several Thomist elements into his own theology, Lonergan did not think one should cling to scholasticism. Likewise, he did not think one could remain content with a biblical approach that reflects representations going back as far as two thousand years: however central and fecund the word of God proves to be in matters of communication, it must be inculturated, that is, rephrased in terms of present-day numerous brands of common sense (see the chapter of Method in Theology entitled "Communications").

Instead, he argued that Christian theologians should accept the modern turn to the subject - anticipated by St. Paul, St. Augustine and others -, try to fathom its potential, and adapt it to the design and purposes of theology. Solely the appropriation of a transcendental - that is, of a universal understanding of the human person could allow theologians to transpose the common-sense idioms of the Bible into today's incalculable sorts of common sense. Only a subject-centred theology, respectful of the revelatory character of Christianity, could mediate between ancient and contemporary forms of common sense, in which the divine message has been, is and will be couched.

Consequently, if we follow Lonergan's lead, the religious phenomena will no longer be interpreted commonsensically or theoretically, namely from the standpoint of the first or of the second realm of meaning, but interiorly, namely from the standpoint of the third realm of meaning. Theological practice done from this standpoint will be more and more helpful in a worldwide mentality that is being vastly influenced by modern psychology. Still, the third realm of meaning, which employs psychological tools, must accord itself to the contents of the fourth realm, called 'transcendence.' Hence the significance of religious experience.

\section{Lonergan's Understanding of Religious Experience}

In Method in Theology as well as in Lonergan's subsequent writings, the concept of religious experience plays a key role. This section will lay out the several elements contained in this concept.

Lonergan speaks of 'experience.' Throughout Western history this term has meant numerous things. ${ }^{13}$ For him, it designates what happens on the first level of intentionality, where the data of sense are perceived and recorded. And it also designates the religious component of the fourth level, namely the awareness of an otherworldly love, felt in oneself as a mysterious gift. In both cases, there is a direct contact with a certain presence - physical or

\footnotetext{
${ }^{13}$ On the concept of experience, see ROY, Louis, Transcendent Experiences, chap. 9, section entitled "Experience."
} 
spiritual - which has yet to be understood (on the second level), while this understanding still has to be pronounced true (on the third level) and to be pronounced valuable (on the fourth level).

In the years following the publication of Method in Theology Lonergan identified two movements in intentionality: from below upward and from above downward. As adumbrated in my section on intentionality, the former starts with the first level, namely with the sensitivity that we share with animals. It remains that these are confined to a habitat, whereas we humans move beyond our immediate surroundings and have access to a world mediated by meaning. It is our capacity to question that enables us to go beyond the infant's world of immediacy and, indeed, to go beyond ourselves towards what is not ourselves, as we progressively encounter meaning, truth and value. Lonergan observes that, on the fourth level, the intentionality that transcends itself can be fulfilled when one lives in a state of love, either with one's husband or wife, or with parents or children, or with fellow citizens, or with God.

It is on the fourth level that Lonergan positions religious experience. Then one is attracted not only to limited values but, rather, one apprehends ultimate value. This experience amounts to the religious aspect of the fourth level, namely the aspect concerned not with finite values, but with infinite value. A unique affective state establishes itself: being in love in an unrestricted fashion. Lonergan avers that this affective state consists not in knowledge, but in consciousness.

To say that this dynamic state is conscious is not to say that it is known. For consciousness is just experience, but knowledge is a compound of experience, understanding, and judging. Because the dynamic state is conscious without being known, it is an experience of mystery (Method in Theology, 106).

The consciousness he is talking about is experience not on the first but on the fourth level of intentionality.

It is this consciousness as brought to a fulfilment, as having undergone a conversion, as possessing a basis that may be broadened and deepened and heightened and enriched but not superseded ... . So the gift of God's love occupies the ground and root of the fourth and highest level, of man's intentional consciousness. It takes over the peak of the soul, the apex animae (107).

However, when one becomes aware of this consciousness, there begins the knowledge of it, which Lonergan calls 'faith.' Faith is "the eye of religious love, an eye that can discern God's self-disclosures" (119). He defines faith and he unpacks the context in which it emerges, by having recourse to a famous dictum of Blaise Pascal: 
Faith is the knowledge born of religious love.

First, then, there is a knowledge born of love. Of it Pascal spoke when he remarked that the heart has reasons which reason does not know. Here by reason I would understand the compound of the activities on the first three levels of cognitional activity, namely, of experiencing, of understanding, and of judging. By the heart's reasons I would understand feelings that are intentional responses to values . . . Finally, by the heart I understand the subject on the fourth, existential level of intentional consciousness and in the dynamic state of being in love. The meaning, then, of Pascal's remark would be that, besides the factual knowledge reached by experiencing, understanding, and verifying, there is another kind of knowledge reached through the discernment of value and the judgments of value of a person in love (115).

So far I have described the movement from below upward, which ascends towards the experience of being in love unconditionally. The complementary movement, from above downward, is launched at the fourth level, more precisely in the religious aspect of that level, and it triggers various kinds of response at the lower levels. It descends from hearing, so to speak, an inner word of transcendent love, to its outer forms of expression, until it reaches the stage of action. In chapter 4 of Method in Theology we find an enumeration of those religious discoveries, Unfortunately the succession of those discoveries remains partly implicit. Perhaps the sequence could be clarified as follows: a basic state of being in love unrestrictedly (prior word, also called inner word) ? faith (the knowledge born of religious love) ? the word as expressed (outer word) ? belief (judgments of fact and of value to which one adheres) ? action in the world (thanks to a self-transcendence that undoes decline and promotes progress in society).

In this sequence it is easy to observe a succession of mutual influences between the cognitive and the affective in the human person. At every level of intentionality, a combination of the cognitive and the affective is present. It is mostly at the first three levels that cognitive operations predominate, and mostly at the fourth level that affective states predominate.

Incidentally, the primacy of love permits us to place Lonergan's view of religious experience within one of the medieval spiritual traditions, which culminates in the wonderful classic entitled The Cloud of Unknowing. He mentions the theme of the cloud a few times in Method in Theology. Twice he gives the reference to a fellow Jesuit's study on that work, about which he avows: "I have found extremely helpful William Johnston's The Mysticism of the Cloud of Unknowing, New York, Rome, Tournai, Paris: Desclée, 1967. Readers wishing to fill out my remarks will find in his book a position very largely coherent with my own" (342, note 7; see 29 and 266). Lonergan's description of religious experience equates it with mysticism; it has the advantage of situating mysticism with respect to the whole of human experience, namely with respect to the overall intentionality. 
Moreover, Lonergan talks about the centrality of conversion, which profoundly affects the person. A conversion is more than a development: whereas the latter operates horizontally, within the same horizon, the former operates vertically. It involves an ascent, a change of horizons, thanks to which people become very different from what they were. He describes three conversions as follows.

Intellectual conversion depends on overcoming false construals of knowledge, objectivity and reality. Human knowing is not the equivalent of merely seeing what is out there now to be looked at; this account would reduce knowing to the first level of intentionality. Objectivity requires more than observing the data with exactitude; it encompasses insight and judgment. Reality comprehends infinitely more than the world of immediacy in which infants move; it must be defined as the world mediated by meaning, in which adults think, love and decide.

Knowing, accordingly, is not just seeing; it is experiencing, understanding, judging, and believing. The criteria of objectivity are not just the criteria of ocular vision; they are the compounded criteria of experiencing, of understanding, of judging, and of believing. The reality known is not just looked at; it is given in experience, organized and extrapolated by understanding, posited by judgment and belief (238).

We shall return to this issue of objectivity. For now, however, let us very briefly characterize moral conversion, which is not essential for our purposes in this essay on religious experience. "Moral conversion changes the criterion of one's decisions and choices from satisfactions to value. . . . [It] consists in opting for the truly good, even for value against satisfaction when value and satisfaction conflict" (240). It takes place when people decide to be fully responsible and to accept the existential fact that willynilly they become what they freely make of themselves. And as far as religious conversion is concerned, there is no need to describe it at this point, since it is the same as religious experience, which was unpacked earlier in this section.

Lastly, basing himself on passages of Lonergan's work Insight, which deal with the psychological dimension of the human person, the American Jesuit Robert Doran submitted that there exists a fourth conversion, which he called 'psychic conversion. ${ }^{14}$ Lonergan concurred with the fact of that fourth conversion. It refers to the role played by the human psyche, with its affects and images, in the process of moral conversion. The life of the psyche can either block or facilitate conversion. I myself have preferred to

${ }^{14}$ See DORAN, Robert M., Psychic Conversion and Theological Foundations: Toward a Reorientation of the Human Sciences (Chico, CA: Scholars Press, 1981). 
attach to ethics this psychic collaboration and to consider the psychological and moral conversion as one. ${ }^{15}$

Conversion has a big impact on the way people read the Bible or, for that matter, any classic. Lonergan states:

The major texts, the classics, in religion, letters, philosophy, theology, not only are beyond the initial horizon of their interpreters but also may demand an intellectual, moral, religious conversion of the interpreter over and above the broadening of his horizon. . . .

This is the existential dimension of the problem of hermeneutics. It lies at the very root of the perennial divisions of mankind in their views on reality, morality, and religion (Method in Theology, 161).

Another Canadian philosopher, Donald Evans, says the same thing: "There is a personal or existential prerequisite for understanding biblical language correctly. One must have a rapport or affinity with the divine if one is to understand talk about the divine."16 Both Lonergan and Evans clearly underlines the relation between the readers' existential transformation and their adequate interpretation of religious texts.

\section{An Integration of Faith and Reason}

Having spelled out the elements that Lonergan discerns within religious experience, let us pay some attention to another of his accomplishments, which consists in clarifying how faith and reason work hand in hand something he does from the vantage point of the human subject.

ince Luther, most theologians, spiritual writers and catechists downplayed human reason and extolled personal experience. In reaction against the rationalism of the late Medieval Ages that is noticeable in Scotus, Ockham and the Nominalists, as well as against the modern rationalism that is evident in Descartes, those theologians, spiritual writers and catechists turned their back on the intellect: they took away from the intellect a good portion of what belongs to it and they transferred that portion to the heart. By contrast, we find in Method in Theology a remarkable integration of faith and reason. Let us examine how Lonergan has achieved a synthesis that brings together intellectuality and affectivity. There are four points to be considered.

\footnotetext{
${ }^{15}$ See ROY, Louis, Coherent Christianity (Ottawa, Novalis, 2005), chap. 2, section 5. There is a later, slightly expanded, French version: La foi en dialogue (Ottawa: Novalis, 2006).

${ }^{16}$ EVANS, Donald, Faith, Authenticity, and Morality (Toronto: University of Toronto Press, 1980), 249; his italics.
} 
For one thing, religious experience is situated within the overall dynamism of human intentionality. It is definitely not isolated from the rest of human life. Lonergan locates it in the domain of transcendence, which he also calls 'religion.' This domain is reached on the top floor of intentionality, namely on the fourth level, which, for him, is the level of affectivity par excellence, even though feelings are present at all levels. We can easily observe that, in his view, religious affectivity is not divorced from religious intellectuality. In fact, the vector that is questioning and the state of being in love are parallel: "Just as unrestricted questioning is our capacity for selftranscendence, so being in love an unrestricted fashion is the proper fulfilment of that capacity" (106).

The second thing to notice is that Lonergan commences chapter 4 of Method in Theology, entitled "Religion," with a section called "The Question of God" (101-3). This question is the most radical of all questions, for it amounts to questioning our own questioning, to ask about the significance of human questioning as a whole. It is introduced as threefold, according to the approach of intentionality analysis, although we shall soon find out that actually it is fourfold. The question of God can be raised on the second, third or fourth level of intentionality. At each level, there is a reduplication, for we can successively wonder about the meaning of meaning, the truth of truth, and the value of value. The following text makes it clear that the proof successively operates on the second, third and fourth level of intentionality: "We can inquire into the possibility of fruitful inquiry. We can reflect on the nature of reflection. We can deliberate whether our deliberating is worth while" (101).

As regards the intelligibility of inquiry, the author explains:

Implicitly we grant that the universe is intelligible and, once that is granted, there arises the question whether the universe could be intelligible without having an intelligent ground. But that is the question about God (101).

As regards the rationality of reflection, we realize that it engages in making possible judgments which are at first conditioned, hence not unconditioned but merely virtually unconditioned, that is, which are true if certain conditions are met. Given this analysis of the act of judging, we can naturally think of the notion of an absolutely unconditioned.

The virtually unconditioned has no unfulfilled conditions. The strictly unconditioned has no conditions whatever. In traditional terms, the former is a contingent being, and the latter is a necessary being. In more contemporary terms the former pertains to this world, to the world of possible experience, while the latter transcends this world in the sense that its reality is of a totally different order. But in either case we come to the question of God. Does a necessary being exist? Does there exist a reality that transcends the reality of this world? (102) 
As regards the value of deliberation, the author lists a series of questions:

Has "worth while" any ultimate meaning? Is moral enterprise consonant with this world? We praise the developing subject ever more capable of attention, insight, reasonableness, responsibility. We praise progress and denounce every manifestation of decline. But is the universe on our side, or are we just gamblers and, if we are gamblers, are we not perhaps fools, individually struggling for authenticity and collectively endeavouring to snatch progress from the ever mounting welter of decline? The question arise and, clearly, our attitudes and our resoluteness may be profoundly affected by the answers. Does there or does there not necessarily exist a transcendent, intelligent ground of the universe? Is that ground or are we the primary instance of moral consciousness? Are cosmogenesis, biological evolution, historical process basically cognate to us as moral beings or are they indifferent and so alien to us? (102-3)

Further on in the book, the author encapsulates his threefold path to the existence of God, as he links up our affective concern with our fundamental questioning:

One's fundamental concern springs from God's gift of his love, but one's questions begin from the world and from man. Could the world be mediated by questions for intelligence if it did not have an intelligent ground? Could the world's facticity be reconciled with its intelligibility, if it did not have a necessary ground? Is it with man that morality emerges in the universe so that the universe is amoral and alien to man, or is the ground of the universe a moral being? (342)

However, given the importance of faith as a basic state of being-in-love, the question of God acquires a fourth dimension. Although the three intellectual components of the question are by no means abolished, later in chapter 4 they are nonetheless transposed into a new, dramatic and interpersonal setting, owing to "an apprehension of transcendent value":

This apprehension consists in the experienced fulfilment of our unrestricted thrust to self-transcendence, in our actuated orientation towards the mystery of love and awe. Since that thrust is of intelligence to the intelligible, of reasonableness to the true and the real, of freedom and responsibility to the truly good, the experienced fulfilment of that thrust in its unrestrictedness may be objectified as a clouded revelation of absolute intelligence and intelligibility, absolute truth and reality, absolute goodness and holiness. With that objectification there recurs the question of God in a new form. For now it is primarily a question of decision. Will I love him in return, or will I refuse? Will I live out the gift of his love, or will I hold back, turn away, withdraw? Only secondarily do there arise the questions of God's existence and nature, and they are the questions either of the lover seeking to know him or of the unbeliever seeking to escape him (115-6).

The third noteworthy thing is that, in chapter 11, entitled "Foundations," the author places religious experience at the very centre of theology, which 
is, after all, an intellectual enterprise. And yet, this enterprise requires that the person of the theologian be transformed, according to the three conversions mentioned above. Such a construal of theology applies, not only to Christianity, but to any religion that carries with it a belief in God (for instance, Judaism, Islam, Hinduism) and even to a non-theistic religion (such as Buddhism). Lonergan's ecumenism is broader than the dialogue between the Christian churches. It extends to all world religions, even though he himself did not engage in specific analyses of non-Christian religions. His contribution was methodological: elaborating the principles of a cross-cultural theology. ${ }^{17}$

At any rate, by paying attention to chapter 5, entitled "Functional Specialties," we find that Lonergan does not make of religious experience the sole basis of the theological enterprise. There are eight functional specialties, divided into two phases. The first phase consists of research (assembling the relevant documents), interpretation (expounding the meaning of the texts), history (discerning the evolution of authors or of periods) and dialectic (lining up the oppositions between theological proposals). The second phase consists of foundations (explicating the three conversions), doctrines (establishing what are the dogmas to be accepted), systematics (arriving at a modest understanding of the contents of the dogmas) and communications (transmitting the religious message in a way at once respectful and critical of the common sense of the people addressed).

Furthermore, a fourth, all-important, tenet of Lonergan's, which helps us to interpret religious experience correctly, is the thesis that "objectivity is simply the consequence of authentic subjectivity, of genuine attention, genuine intelligence, genuine reasonableness, genuine responsibility" (265; see 292). This position entails that there is no objectivity on the first and on the second level of intentionality: only on the third level, the level of truth, is there cognitional objectivity, which must be completed by the full, existential objectivity of the fourth level. On the first two levels, we find merely inchoative objectivity. One becomes objective by obeying, not two, but four transcendental precepts: be attentive, be intelligent, be reasonable, be responsible (20).

Later in the same work, the author adds a fifth precept: be in love (268). As a result, alluding to the experience of otherworldly love, he makes bold to write: "religious conversion is the event that gives the name, God, its primary and fundamental meaning" (350). Nevertheless, we would err if we were to single out religious experience - here called 'religious conversion' - as the sole source of religious objectivity. The age-old temptation of illuminism, that is, of relying only on one's own inner light, precisely consists

${ }^{17}$ See his remarks on CANTWELL SMITH, Wilfred and on PANNIKAR, Raimon, in $A$ Third Collection, passim; see Index of Names. 
in segregating one's personal experience from the other levels of intentionality and setting it aside so as to consider its felt immediacy as an incontrovertible proof of its veracity.

\section{Conclusion}

We have noted the centrality of religious experience in Lonergan's theology. Although the biblical, patristic and medieval writers fathomed religious experience in marvellous fashions, they did not rely on it as much as the moderns do. It is obvious, then, that Lonergan is a modern thinker by virtue of having accepted the turn to the human subject, which we can observe in Luther, Descartes and countless others.

Nonetheless, he knew that adopting this stance had its risks. Since the nineteenth century, the Catholic Church's authorities have been wary of the theologies based on religious experience. ${ }^{18}$ Given that the brilliant Schleiermacher, whose theology stems from religious experience, did not manage to avoid relativism, and that most systems of thought whose foundation is religious experience have been incapable of justifying the possibility of reaching truth, we can say that, by comparison, Lonergan's contribution is remarkably sound both philosophically and theologically. Philosophically, it is grounded in a detailed epistemology, articulated in Insight and summed up in the first chapter of Method in Theology; theologically, it is grounded in the gifts of love and light granted by the Holy Spirit.

Like Schleiermacher and so many other Christian thinkers, Lonergan situates religious experience at the core of theology. ${ }^{19}$ However, unlike Schleiermacher, he thinks that a Christian community is not limited to the viewpoint of an epoch. For him, far from being subjectivistic, authentic subjectivity reaches objectivity. Given divine grace, the human person is capable of self-transcendence, and this attitude implies that one is open to what is said by other people and, indeed, by the Other. Consequently Lonergan sees the authentic subject not only as endowed with a receptivity to the wisdom of a religious tradition - a receptivity qualified by what the

\footnotetext{
${ }^{18}$ On the Protestant side, Karl Barth and other Neo-orthodox theologians have vehemently opposed Schleiermacher and his liberal epigones. Like the Catholic authorities, they have been concerned about the subjectivism of the proponents of religious experience. However, in contradistinction to Catholics, who have defended the normativity of a Tradition safeguarded by the Holy Spirit, those Protestants have defended the paramount significance of a Revelation imparted by the Word of God.

${ }^{19}$ In Le sentiment de transcendance, expérience de Dieu? (Paris: Cerf, 2000) I have differentiated Lonergan's concept of religious experience into four main types and I have endeavoured to show the pastoral implications of a theology that takes seriously what I call 'transcendent experiences.'
} 
individual or the group happens to understand -, but as willing to embrace the doctrinal corpus of a religious tradition. This doctrinal corpus, which is the natural development of the outer word, confirms and helps us deepen the inner word that has been experienced. In this way, objectivity, both theological and philosophical, is more emphasized by Lonergan than by most modern authors.

Moreover, by synthesizing the several components of human intentionality and by differentiating the realms of meaning, Lonergan manages to provide an account of the subjective side of Christianity that is admirably balanced and fair. He also elucidates the interrelations between affectivity and intellectuality. Man's loving impulse and questioning intentionality are two dynamisms that work in tandem. Both are connected with the dogmatic side of Christianity, which is presented as an answer to the affective yearning and to the intellectual quest of humanity. For Lonergan, insofar as the reception of doctrines is accompanied by a lively search for understanding, the doctrines enable us to safeguard both love and truth.

Thus reason and faith are united in a way that differs from premodern accounts, even from the one we find in Thomas Aquinas, although it is obvious that Lonergan has been greatly inspired by his medieval mentor. ${ }^{20}$ In fact, his vision is a transposition of Aquinas's thought into a conceptuality that is governed, not by theory (as in Aquinas), but by an intentionality analysis that has thematized interiority. In particular, his thematization of interiority owes much to St Augustine and to John Henry Newman. ${ }^{21}$

\author{
Address: \\ Collège Universitaire Dominicain \\ 96 Empress Avenue \\ Ottawa, ON, K1R 7G3 \\ Canada \\ e-mail: roylouisop@yahoo.com
}

\footnotetext{
${ }^{20}$ To assess the influence of Aquinas on Lonergan, see Verbum: Word and Idea in Aquinas, ed. Frederick E. Crowe and Robert M. Doran, Collected Works of Bernard Lonergan, vol. 2 (Toronto: University of Toronto Press, 1997).

${ }^{21}$ On Augustine's influence in matters of self-knowledge see Lonergan's Introduction to Verbum; on Newman's influence see A Second Collection: Papers by Bernard J. F. Lonergan, S. J., ed. William F. J. Ryan and Bernard J. Tyrrell (Toronto: University of Toronto Press, 1996), 38, 273, 276, and Caring about Meaning: Patterns in the Life of Bernard Lonergan, ed. Pierrot Lambert, Charlotte Tansey, Cathleen Going (Montreal: Thomas More Institute, 1982), 13-14, 20, 46, 257.
} 